\title{
Pengaruh family types, family stages dan household decision terhadap Pengambilan Keputusan Pembelian Pada Mobil Keluarga di Kota Kediri
}

\author{
Gandung Satriyono \\ Fakultas Ekonomi Universitas Kadiri \\ gandungsatriyono@unik-kediri.ac.id
}

\begin{abstract}
The car industry in Indonesia experienced significant growth. Family car is the highest selling car. This study discusses the effects of Family Types, Family Stages, and Household Conflict on making family car purchase decisions in the City of Kediri. The sample of this study amounted to 96 consumers who had purchased a family car in Kota Kediri. Research data from each variable indicator is processed / tabulated, tested for reliability validity and then processed using SPSS. The results of the $t$ test can be concluded that each dimension of the family types, family stages, and household decision variables significantly influences the purchase decision of the family car. The dimension that most influences the purchase decision of a family car is the Household decision (X3) because the t count is the largest, namely 3,441. Resulting in the significance of significance is the significance value of the $F$ test is 0.00 or less than $0.05(\alpha=5 \%)$, it can be concluded that the independent variables are Family Types (X1), Family Stages (X2) and Household decision dimensions (X3) together have a significant effect on family car purchase decisions
\end{abstract}

Keywords: Family Types, Family Stages, Household decision, Decision Making

\begin{abstract}
Abstrak
Industri mobil diIndonesia mengalami pertumbuhan yang cukup signifikan. Mobil keluarga merupakan mobil dengan penjualan tertinggi. Penelitian ini membahas mengenai pengaruh Family Types, Family Stages, dan Household Conflict terhadap pengambilan keputusan pembelian mobil keluarga di Kota Kediri. Sampel penelitian ini berjumlah 96 orang konsumen yang telah melakukan pembelian mobil keluarga di Kota Kediri. Data penelitian dari masing masing indikator variabel diolah/ditabulasi, di uji validitas reliabilitas dan selanjutnya diolah dengan menggunakan SPSS. Hasil uji t dapat disimpulkan bahwa masing masing dimensi variabel family types, family stages, dan household decision mempengaruhi pengambilan keputusan pembelian mobil keluarga secara signifikan. Dimensi yang paling berpengaruh terhadap keputusan pembelian mobil keluarga adalah Household decision (X3) karena t hitungnya paling besar yaitu 3.441. Dihasilkan nilai signifikansi di ba wah nilai signifikansi uji $\mathrm{F}$ adalah 0.00 atau kurang dari $0.05(\alpha=5 \%)$, maka dapat disimpulkan bahwa variabel bebas dimensi Family Types (X1), dimensi Family Stages (X2) dan dimensi Household decision (X3) secara bersama-sama berpengaruh signifikan terhadap keputusan pembelian mobil keluarga
\end{abstract}

Kata Kunci : Family Types, Family Stages, Household decision, Pengambilan Keputusan 


\section{PENDAHULUAN}

\section{Latar Belakang}

Pada dasarnya kegiatan transportasi darat merupakan suatu kegiatan yang sangat vital, jika dibandingkan dengan transportasi laut dan udara. Transportasi darat memiliki rutinitas yang paling tinggi di antara ketiganya ditambah lagi aktivitas yang semakin banyak menuntut setiap manusia untuk memanfaatkan waktu dengan sebaik-baiknya. Hampir setiap kegiatan manusia memerlukan transportasi darat dalam melakukan berbagai aktivitasnya sehari-hari. Terdapat berbagai macam sarana transportasi darat, mobil merupakan salah satunya. Perubahan kondisi perekonomian ke arah yang lebih baik memberikan pengaruh positif bagi pasar otomotif di Indonesia memiliki rutinitas yang paling tinggi di antara ketiganya ditambah lagi aktivitas yang semakin banyak menuntut setiap manusia untuk memanfaatkan waktu dengan sebaik-baiknya.

Transportasi darat yang dipakai mada masa dahulu antara lain yakni sepeda, becak, bajaj, bemo, helicak dan delman. Namun seiring dengan perbaikan sarana dan prasarana transportasi di Indonesia, masyarakat menginginkan alat transportasi yang lebih nyaman dan cepat. Kemudian muncul alat transportasi darat kendaraan bermotor baik yang beroda dua maupun empat. Selain transportasi umum, masyarakat Indonesia juga menggunakan mobil pribadi sebagai alat transportasinya. Penggunaan kendaraan pribadi didorong dengan tingginya aktivitas masyarakat dan juga ketidak puasan terhadap transportasi umum yang ada. Oleh sebab itu kemudian para produsen kendaraan bermotor berlomba-lomba menawarkan produk yang mampu menjawab kebutuhan pasar konsumen mobil pribadi.

"Perkembangan industri mobil di Indonesia mengalami pertumbuhan yang baik. Hal ini dapat kita lihat dari peningkatan jumlah unit mobil yang terjual dari tahun ke tahun Jakarta (ANTARA News)". Sebanyak 1.079.308 unit kendaraan roda empat tercatat telah terjual secara wholesales (pabrik ke dealer) sepanjang tahun 2017, menurut data yang dirilis Gabungan Industri Kendaraan Bermotor Indonesia (Gaikindo).Angka penjualan itu naik tipis ketimbang penjualan tahun 2016 yang sebanyak 1.062.716 unit. Segmen low dan medium MPV yang ditotal mencapai 338.119 unit menjadi penopang penjualan terbesar, diikuti segmen mobil murah ramah lingkungan (LCGC) dan city car sebanyak 266.601 unit, dan segmen low SUV, medium dan high SUV yang mencapai 166.440 unit.Kendati tahun 2017 diramaikan dengan model-model Low MPV terbaru, namun hal itu tidak menggoyahkan Toyota Avanza sebagai kendaraan terlaris 2017 dengan 
penjualan mencapai 116.311 unit, kendati jumlah itu turun dari tahun sebelumnya 122,649 unit. "Toyota Indonesia juga merajai penjualan di dua segmen lain yaitu LCGC 7-penumpang melalui Calya sebanyak 73.236 unit dan Toyota Innova di medium MPV sebanyak 61.775 unit kendaraan (Antara News Otomotif 17 Januari 2018)”.

Konsumen keluarga yang membeli produk mobil keluarga cenderung membawa pasangannya ketika mengunjungi showroom maupun pameran untuk melihat produk. Pasangan dan anak seringkali juga memberikan pendapat baik mengenai tipe ataupun warna yang akan dipilih, namun di karenakan mobil keluarga tidak termasuk produk baru sehingga pada umumnya mereka tidak lagi asing dengan spesifikasi dari produk yang ditawarkan. Mereka sudah mengetahui spesifikasi dari keluarga dan orang-orang terdekat yang telah menggunakan produk tersebut.

Faktor yang menjadi pertimbangan konsumen dalam melakukan pembelian adalah harga yang ditawarkan, ketersediaan unit mobil, bonus yang diberikan, layanan purna jual, dan harga jual kembali produk tersebut. Karakteristik konsumen yang ada cenderung lebih teliti dan kritis ketika akan membeli produk mobil keluarga. Hal ini menyebabkan proses pengambilan keputusan membutuhkan waktu yang lebih lama.

Melihat realita ini dari berbagai aspek dan latar belakang di atas, maka peneliti memilih objek penelitian produk mobil keluarga. Sehungga tujuan dari penelitian ini adalah untuk menganalisis pengaruh Family Types, Family Stages dan Household decision terhadap pengambilan keputusan pembelian mobil keluarga

\section{TINJAUAN PUSTAKA}

\section{Penelitian Terdahulu}

Viesturs Uzulens (2012) dengan judul“Joint-Decision Making Roles Between Spouses in Latvia When Buying A Family Car", peneliti meneliti bagaimana pasangan suami istri di Latvia mengambil keputusan beli mobil ditinjau dari perspektif teoritis serta meneliti peran antara suami istri. Kesimpulannya adalah proses pengambilan keputusan dapat dibagi menjadi faktor individu, keluarga, dan faktor lain. Banyak keputusan diambil bersama apabila pasangan memiliki pandangan yang sama mengenai kesetaraan derajat antara suami istri dan level pendidikan yang sama. Apabila pernah ada konflik dengan orang tua, hanya salah satu pasangan yang tertarik terhadap produk, atau berkontribusi lebih besar mengenai anggaran rumah tangga, keputusan cenderung dilaku secara soliter. Penelitian menunjukkan bahwa peran 
suami dalam pembelian mobil lebih besar dibandingkan istri.Tahap pencarian informasi didominasi oleh pihak suami, sehingga hal ini mengindikasikan pihak suami yang menjadi target marketer. Penerapan strategi pemasaran yang dilakukan harus seimbang antara suami dan istri karena besarnya uang yang dikeluarkan untuk membeli mobil merupakan keputusan bersama.

Siska Limantoro dan Edwin Japarianto, dengan judul analisa pengaruh family types, family stages dan household conflict terhadap pengambilan keputusan pembelian matras king koil di Surabaya. Hasil penelitian menunjukkan secara parsial, dari dimensi family types dengan dimensi nuclear family, family stages yaitu dimensi joint, wife dominant, husband dominant dan household conflict yaitu dimensi accommodative purchase decision berpengaruh signifikan dengan dimensi wife dominant yang berpengaruh paling besar.

\section{Landasan Teori}

\section{Grup}

Menurut Sciffman dan Kanuk (2007), grup adalah "two or more people who interact to accom- plish either individual or mutual goals" atau dua atau lebih orang yang berinteraksi untuk mencapai tujuan individu atau kelompok. Kemudian kita juga mengenal istilah reference group yaitu kelompok yang dijadikan sebagai referensi ketika seseorang memutuskan untuk membeli atau mengkonsumsi suatu produk atau jasa.

Reference group ada 2 jenis yaitu Normative reference group dan Cooperative reference group. Normatice reference group adalah reference group yang mempengaruhi secara umum nilai-nilai dasar serta perilaku seseorang, misalnya keluarga. Sedangkan Comparative reference group adalah reference group yang berfungsi sebagai panutan mengenai sikap atau perilaku seseorang. Contohnya adalah cara hidup tetangga yang tampak mengagumkan dan layak ditiru seperti cara mereka merawat rumah dan sebagainya.

\section{Keluarga}

Menurut Sciffman \& Kanuk (2010, p.316), family atau keluarga adalah “two or more persons related by blood, marriage, or adoption who reside together" yaitu dua orang atau lebih yang berhubungan darah, dalam suatu pernikahan, atau diadopsi yang tinggal bersamasama. 
Keluarga dapat dikatakan rumah tangga, namun rumah tangga dapat terdiri dari keluarga maupun non keluarga. Menurut Sciffman \& Kanuk (2010, p. 306) keluarga mungkin adalah reference group yang memiliki kekuatan yang paling kuat untuk mempe- ngaruhi perilaku konsumen.

\section{Family Types (Tipe Keluarga)}

Ada dua tipe keluarga yaitu (Solomon, 2009, p. 477):

a. Nuclear family (keluarga inti)

Keluarga yang terdiri dari ayah, ibu dan satu atau lebih anak. Jenis keluarga ini cenderung memiliki anggota keluarga yang lebih sedikit dibandingkan dengan extended family. Wewenang yang lebih besar dalam melakukan pengambilan keputusan biasanya pada nuclear family berada ditangan orang tua. Anak dapat melakukan pengambilan keputusan ketika anak tersebut sudah dewasa dan mampu untuk membuat keputusan.

\section{b. Extended family}

Keluarga yang terdiri dari tiga generasi dan tinggal bersama yang biasanya terdiri dari kakek, nenek, paman, bibi dan keponakan. Pola konsumsi extended family tentunya tidak sama dengan nuclear family, dikarenakan jumlah anggota yang ada di rumah tersebut lebih banyak. Pada saat akan membeli suatu produk tentunya pertimbangan yang dilakukan akan lebih banyak.

\section{Family Stages}

Dalam satu rumah tangga biasanya dimulai dengan hubungan pernikahan antara suami dan istri, hal ini menyebabkan marketer tertarik untuk melihat pengaruh mereka dalam pengambilan keputusan konsumsi barang dan jasa. Pengaruh tersebut dapat diklasifikasikan menjadi 4 jenis, yaitu (Sciffman \& Kanuk, 2010, p. 330):

a. Joint (setara antara suami dan istri)

pembelian yang keputusannya dilakukan bersama adalah produk seperti rumah, furnitur ruang keluarga dan liburan.

\section{b. Wife dominated (istri dominan)}

Biasanya pembelian produk yang keputusannya didominasi oleh istri adalah pembelian alat rumah tangga, makanan, dan perlengkapan dapur.

c. Husband dominated (suami dominan) 
Biasanya pembelian produk yang keputusannya didominasi oleh suami adalah pembelian mobil, minuman keras, dan asuransi kesehatan.

d. Autonomic (keputusan sepihak atau soliter) Keputusan yang dibuat perorangan baik suami atau istri saja tanpa menanyakan pendapat dari pasangannya.

Keputusan pembelian suami dan istri juga berelasi dengan pengaruh budaya. Penelitian menunjukan bahwa dalam kebudayaan Cina keputusan pembelian biasanya seimbang antara suami dan istri ( joint) atau lebih didominasi oleh suami (husband dominated). Namun pada kota-kota yang lebih besar biasanya keputusan pembelian lebih banyak dilakukan bersama (joint). Ada empat faktor yang menentukan apakah hal tersebut akan diputuskan secara bersama atau tidak, yaitu :

\section{Sex-role stereotypes}

Keluarga yang menganut sex-role stereotypes secara tradisional lebih sering membuat keputusan secara individual bergantung pada maskulinitas dan feminimitas suatu produk.

\section{Spousal resources}

Anggota keluarga yang berkontribusi lebih besar dalam keuangan rumah tangga memiliki pengaruh yang lebih besar yang menyebabkan ia menjadi lebih dominan atau bahkan dapat membuat keputusan sendiri.

\section{Experience}

Anggota keluarga yang telah terbiasa untuk membuat keputusan akan lebih sering lagi untuk membuat keputusan dimasa depannya.

\section{Socioeconomic status}

Keluarga menengah lebih sering membuat keputusan bersama apabila dibandingkan dengan keluarga menengah keatas dan bawah.

\section{Household Decision}

Proses pengambilan keputusan keluarga dalam rumah tangga, sama seperti konfrensi bisnis. Setiap anggota keluarga memiliki aktivitas dan prioritas yang berbeda beda, sehingga memungkinkan untuk terjadi perebutan kekuasaan untuk bersaing dalam setiap intrik permasalahan yang ada. Ada 2 tipe dasar pengambilan keputusan dalam keluarga (Solomon, 2009, p.484) :

a. Consencual purchase decision 
Anggota keluarga setuju pada pembelian yang akan dilakukan, yang membedakan adalah bagaimana cara untuk mencapai hal tersebut. Contohnya, keluarga setuju untuk membeli mobil yang baru, namun ada perbedaan pendapat antara membelinya langsung ke dealer atau pameran.

\section{b. Accomodative purchase decision}

Anggota keluarga memilki preferensi dan prioritas yang berbeda namun mereka setuju untuk melakukan pembelian. Contohnya ketika suami menginginkan untuk membeli mobil baru, istri tidak dapat melihat pentingnya kebutuhan untuk mengganti mobil yang lama.

Adapun beberapa faktor yang mempengaruhi munculnya perbedaan pendapat atau tidak adalah :

\section{a. Interpersonal need}

Yaitu tingkat keterlibatan seseorang dalam kelompok. Anggota keluarga yang tinggal bersama cenderung me miliki keterlibatan yang lebih besar dalam mengambil keputusan dibandingkan anggota keluarga yang tidak tidak satu rumah.

\section{b. Product involvementand utility}

Yaitu frekuensi anggota keluarga dalam menggunakan produk. Anggota keluarga yang lebih sering menggunakan produk yang akan dibeli cenderung untuk lebih mempertahankan pendapatnya mengenai produk tersebut dibandingkan dengan keluarga yang tidak menggunakan produk tersebut.

\section{c. Responsibility}

Yaitu siapa yang bertanggung jawab dalam perawatan dan pembayaran produk yang akan dibeli. Anggota keluarga yang tidak bertanggung jawab atas produk tersebut cenderung akan lebih sedikit memberikan pendapatnya dan akan mengikuti pendapat anggota keluarga lainnya.

\section{d. Power}

Yaitu kemampuan salah satu anggota dalam mempengaruhi anggota lain dalam membuat keputusan. Ketika muncul konflik, anggota keluarga yang memiliki kekuatan lebih akan berusaha me mbuat anggota keluarga lainnya menyetujui pendapat yang dibuatnya. 


\section{Keputusan Pembelian}

Pada akhirnya yang menjadi tujuan akhir dari seluruh strategi pemasaran adalah konsumen memilih produknya ketika mengambil keputusan beli. Keputusan pembelian menurut (Blackwell \& Miniard,2006, p. 210) adalah "the selection of an option from two or alternative choice". Jadi, keputusan pembelian adalah suatu keputusan seseorang dimana individu tersebut memilih salah satu dari beberapa alteratif yang dimilikinya.

\section{Kerangka Berpikir}

Gambar 2.1 : Kerangka Berpikir

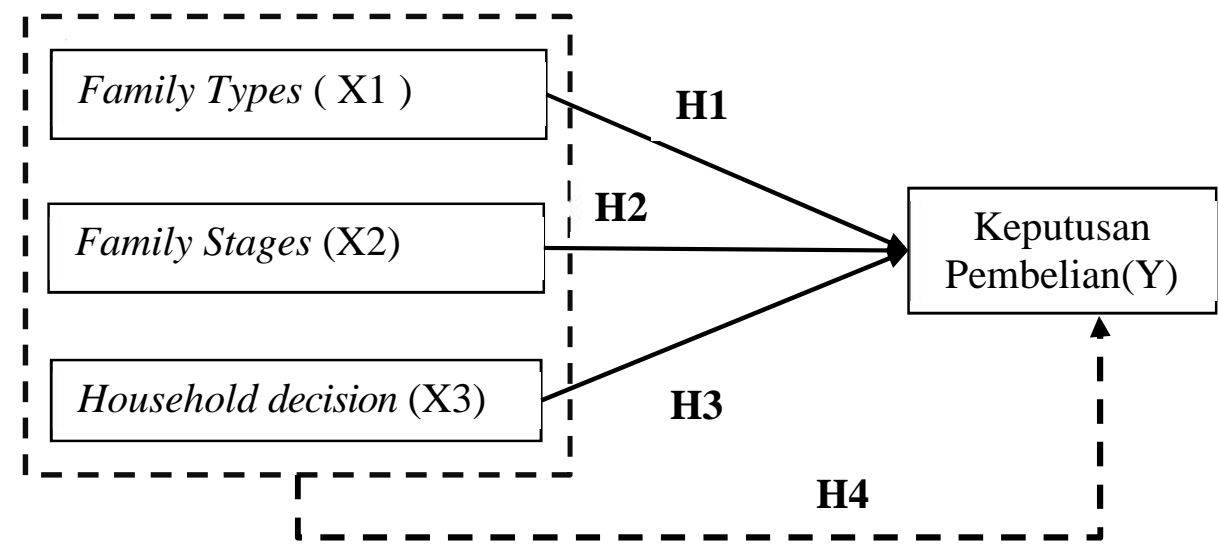

Sumber : (Solomon, 2009,)

\section{Hipotesis}

H1 : Family types berpengaruh secara positif terhadap keputusan pembelian.

$\mathrm{H}_{2}$ : Family stages berpengaruh secara positif terhadap keputusan pembelian.

$\mathrm{H} 3$ : Household decision berpengaruh secara positif terhadap keputusan pembelian.

H4 : Family types, Family stages dan Household decision berpengaruh secara bersama sama terhadap keputusan pembelian.

\section{METODE PENELITIAN}

\section{Populasi dan Sampel}

Populasi adalah kelompok elemen yang lengkap yang biasaya berupa orang, obyek, transaksi atau kejadian dimana peneliti tertarik untuk mempelajari- nya atau menjadi obyek 
penelitian (Kuncoro, 2003, p.103). Dalam penelitian ini populasinya adalah seluruh pasangan suami istri yang tinggal di Kediri dan berminat membeli mobil keluarga.

Sampel adalah bagian dari jumlah dan karakteristik yang dimiliki oleh populasi tersebut (Sugiyono, 2016). Teknik yang dipilih adalah purposive sampling yaitu penarikan sampel berdasarkan kriteria tertentu yang telah ditetapkan peniliti dengan mengasumsikan populasi tidak terbatas. Ukuran populasi dalam penelitian ini sangat banyak dan tidak dapat diketahui dengan pasti, maka besar sampel yang digunakan (Purba, 2006) dalam (Kharis, 2011:50) menggunakan rumus sebagai berikut :

$\mathrm{N}=\frac{\mathrm{Z}^{2}}{4(\mathrm{M})^{2}}$

Ket :

$\mathrm{n}=$ ukuran sampel

$\mathrm{Z}=1,96$ score pada tingkat signifikasi tertentu (derajat ditentukan 95\%)

Moe $=$ Margin off error, tingkat kesalahan maksimum 10\% maka :

$\mathrm{n}=\frac{(1,9)^{2}}{4(1 \%)^{2}}$

$\mathrm{n}=96,04=96$ responden .

\section{Variabel dan Definisi Operasional Variabel}

Jenis penelitian yang dilaku kan oleh penulis adalah penelitian kuantitatif kausal. Sedangkan variabel yang digunakan adalah faktor-faktor yang dapat mempengaruhi keluarga dalam mengambil suatu keputusan pembelian mobil keluarga. Adapun variabel independent tersebut adalah :

1. Family Types (X1)

a. Nuclear Family (X1.1); diukur melalui kontribusi pasangan, pendapat anak dan pendapat diri sendiri

b. Extended Family (X1.2); di ukur melalui pendapat orang tua dan sanak saudara

2. Family Stages (X2)

a. Joint (X2.1); di ukur dari semua keputusan dan inisiatif bersama

b. Wife Dominated (X2.2); di ukur dari pendapat dan insiaiatif istri

c. Husband Dominated (X2.3); di ukur dari pendapat dan inisiatif suami

d. Autonomic (X2.4); di ukur dari pendapat dan inisiatif langsung tanpa 
melibatkan pasangan

\section{Household decision (X3)}

a. Consensual Purchase Decision (X3.1); di ukur melalui kesamaan pandangan pasangan dan penyelesaiannya

b. Accomodative purchase decision (X3.2) diukur melalui keberbedaan pandangan pasangan dan penyelesaiannya.

4. Variabel dependent keputusan pembelian (Y)

Variabel Y dalam penelitian ini adalah keputusan pembelian dimana konsumen memilih dari beberapa alternatif yang dimiliki

\section{Metode Pengu mpulan Data}

Metode pengumpulan data adalah metode atau cara yang digunakan dalam mengu mpulkan sumber data, beberapa cara diantaranya adalah:

a. Studi Literatur

Studi kepustakaan sebagai daftar penelitian dalam pembuatan analisis teori. Caranya adalah dengan membaca buku karya ilmiah yang telah ditulis oleh para ahli mengenai consumer behavior atau yang biasa kita sebut dengan perilaku konsumen. Perilaku konsumen yang dipelajari adalah perilaku pelanggan keluarga dan bagaimana pengaruhnya terhadap pengambilan keputusan pembelian.

b. Studi Lapangan

Yaitu pengumpulan data secara langsung yang dilakukan pada obyek penelitian sebagai data primer. Penelitian ini meliputi penyebaran kuisioner dengan menggunakan skala likert.

\section{Teknik analisa Data}

Adapun beberapa uji yang dilakukan dalam penelitian ini adalah:

1. Uji Validitas dan Reabilitas

penelitian dikatakan valid apabila alat ukur untuk mendapatkan data tersebut valid, yaitu dapat mengukur apa yang seharusnya diukur, sedangkan uji reabilitas digunakan untuk memastikan bahwa responden cukup konsisten

2. Uji asumsi klasik

Uji asumsi yang dilakukan sebelum melakukan uji regresi linier berganda adalah uji multikolonieritas dan uji normalitas. 


\section{Analisis Regresi Linier Berganda}

Analisis regresi linier berganda adalah hubungan secara linear antara dua atau lebih variabel independen $(\mathrm{X} 1, \mathrm{X} 2, \ldots . \mathrm{Xn})$ dengan variabel dependen $(\mathrm{Y})$. Analisis ini digunakan untuk mengetahui arah hubungan antara variabel independen dengan variabel dependen apakah masing masing independen berhubungan positif atau negatif dan untuk meprediksi nilai dari variabel dependen apabila nilai variabel independent mengalami kenaikan atau penurunan.

4. Uji t (uji parsial)

Uji t digunakan untuk menguji signifikasi konstanta dari variabel bebas secara parsial atau individual terhadap variabel terikat.

Pengujian ini dilakukan dengan menggunakan taraf signifikan dibawah 0,05 (5\%), maka secara parsial atau individual variabel bebas berpengaruh signifikan terhadap variabel terikat, begitu juga sebaliknya.

Menurut (Kosnendi, 2005 :12) :

Rumus uji thitung :

$$
t=\frac{b_{i}}{S_{i}}
$$

Dimana :

$b_{i}$ : Koefisien regresi

$S b_{i}$ : Standart error koefisien regresi

Kriteria Pengambilan Keputusan:

1. Jika Signifikan $t<0,05$ maka Ho di tolak jadi dapat disimpulkan bahwa ada pengaruh yang signifikan antara variabel-variabel bebas berupa kualitas produk $\left(\mathrm{X}_{1}\right)$, harga $\left(\mathrm{X}_{2}\right)$ terhadap pengambilan keputusan pembelian $(\mathrm{Y})$.

2. Jika Signifikan $t>0,05$ maka dapat disimpulkan bahwa tidak ada pengaruh yang signifikan antara variabel-variabel bebas berupa kualitas produk $\left(\mathrm{X}_{1}\right)$, harga $\left(\mathrm{X}_{2}\right)$ terhadap pengambilan keputusan pembelian (Y).

Semua analisis dihitung dengan program SPSS sehingga korelasi dalam perhitungan dapat dipercaya.

5. Uji F (uji simultan)

Uji F digunakan untuk menguji variabel-variabel bebas secara bersama-sama (simultan) terhadap variabel terikat. Pengujian ini dilakukan dengan cara menggunakan taraf signifikansi dibawah 0,05 (5\%) maka secara bersama-sama 
(simultan) variabel bebas berpengaruh signifikan terhadap variabel terikat, begitu juga sebaliknya. Rumus yang dikemukakan oleh Sugiono (2004:190) untuk mengetahui nilai $F_{\text {hitung, yaitu: }}$

$$
F=\frac{R^{2} / k}{\left(1-R^{2} /(n-k-1)\right.}
$$

Dimana:

$F=F_{\text {hitung }}$ yang selanjutnya dibandingkan dengan $F_{\text {tabel }}$

$R^{2}=$ Koefisien determinasi

$n=$ Jumlah sampel

$k=$ Jumlah variabel bebas (independen variabel)

Kriteria Pengambilan Keputusan :

1. Jika taraf Signifikan $f<0,05$ maka Ho ditolak, berarti ada pengaruh yang signifikan antara variabel kualitas produk dan harga secara simultan dengan keputusan pembeli diterima.

2. Jika taraf Signifikan $f>0,05$ maka Ho diterima, berarti tidak ada pengaruh yang signifikan antara variabel kualitas produk dan harga secara simultan dengan keputusan pembeli ditolak.

6 Uji Koefisien Determinasi (R2 )

Menurut Ghozali (2001:83) koefisien determinasi (R2) pada intinya mengukur seberapa jauh kemampuan model dalam menerangkan variasi variabel dependen. Nilai koefisien determinasi adalah antara nol (0) sampai satu (1). Jika koefisien determinasi nol berarti variabel independen sama sekali tidak berpengaruh terhadap variabel dependen. Apabila koefisien determinasi semakin mendekati satu, maka dapat dikatakan bahwa variabel independen berpengaruh terhadap variabel dependen. Nilai koefisien determinasi ditentukan dengan nilai $R$ square .

\section{HASIL DAN PEMBAHASAN}

\section{Validitas}

Uji validitas digunakan untuk mengukur sah/valid atau tidaknya suatu kuesioner. Kuesioner dikatakan valid jika pertanyaan pada kuesioner mampu untuk mengungkapkan sesuatu yang akan diukur oleh kuesioner tersebut. Kriteria yang 
digunakan atau batas minimum suatu instrumen/angket dinyatakan valid atau dianggap memenuhi syarat ada beberapa cara antara lain:

a. Harga koefisien korelasi yang diperoleh dari analisis dibandingkan dengan harga koefisien korelasi pada tabel dengan tingkat kepercayaan yang telah dipilih.

b. Harga koefisien korelasi antara butir dengan skor total kurang dari 0,3 maka butir atau item pertanyaan dalam instrumen tersebut dinyatakan tidak valid. Dengan demikian suatu instrumen dinyatakan valid apabila harga koefisien $r$ hitung $\geq 0,3$. (Dari teori Sugiyono 2012-126). Berikut dibawah adalah hasil Uji Validitas :

Tabel 4.1 : Hasil Uji Validitas

\begin{tabular}{|l|l|l|l|l|}
\hline No & Pernyataan & R hitung & R tabel & Keterangan \\
\hline 1 & X1.1 & 0,785 & 0,203 & Valid \\
\hline 2 & $\mathrm{x} 1.2$ & 0,806 & 0,203 & Valid \\
\hline 3 & $\mathrm{x} 1.3$ & 0,833 & 0,203 & Valid \\
\hline 4 & $\mathrm{x} 1.4$ & 0,725 & 0,203 & Valid \\
\hline 5 & $\mathrm{X} 2.1$ & 0,740 & 0,203 & Valid \\
\hline 6 & $\mathrm{X} 2.2$ & 0,742 & 0,203 & Valid \\
\hline 7 & $\mathrm{X} 2.3$ & 0,855 & 0,203 & Valid \\
\hline 8 & $\mathrm{X} 2.4$ & 0,827 & 0,203 & Valid \\
\hline 9 & $\mathrm{X} 2.5$ & 0,766 & 0,203 & Valid \\
\hline 10 & $\mathrm{X} 3.1$ & 0,793 & 0,203 & Valid \\
\hline 11 & $\mathrm{X} 3.2$ & 0,757 & 0,203 & Valid \\
\hline 12 & $\mathrm{X} 3.3$ & 0,665 & 0,203 & Valid \\
\hline 13 & $\mathrm{X} 3.4$ & 0,629 & 0,203 & Valid \\
\hline 14 & Y1.1 & 0,778 & 0,203 & Valid \\
\hline 15 & Y1.2 & 0,708 & 0,203 & Valid \\
\hline 16 & Y1.3 & 0,728 & 0,203 & Valid \\
\hline 17 & Y1.4 & 0,652 & 0,203 & Valid \\
\hline 18 & Y1.5 & 0,530 & 0,203 & Valid \\
\hline
\end{tabular}

Sumber : Data Primer diolah 2018

Dari tabel 4.1 diperoleh hasil $r$ hitung lebih dari $r$ tabel dengan demikian instrumen dinyatakan valid.

\section{Uji Reliabilitas}

Reliabilitas adalah alat untuk mengukur suatu kuesioner yang merupakan indikator dari variabel atau konstruk. Butir pertanyaan dikatakan reliable atau andal apabila jawaban seseorang terhadap pertanyaan adalah konsisten. Instrumen yang reliabel akan menghasilkan data yang sesuai dengan kondisi sesungguhnya. Dalam penelitian ini uji reliabilitas dengan menggunakan kaidah alpha cronbach. dimana suatu variabel laten dikatakan reliable jika nilai Alpha Cronbach > 0,6 (Arikunto,2002:152). Berikut dibawah adalah hasil uji reliabilitas : 
Tabel 4.2 : Hasil Uji Reliabilitas

\begin{tabular}{|l|l|l|l|l|}
\hline No & Pernyataan & Cronbach's Alpha & Batas toleransi & Keterangan \\
\hline 1 & $\mathrm{X} 1$ & 0,806 & 0,60 & Reliabel \\
\hline 2 & $\mathrm{X} 2$ & 0,803 & 0,60 & Reliabel \\
\hline 3 & $\mathrm{X} 3$ & 0,788 & 0,60 & Reliabel \\
\hline 4 & $\mathrm{Y}$ & 0,771 & 0,60 & Reliabel \\
\hline
\end{tabular}

Sumber : Data Primer diolah 2018

Pada tabel 4.2 menunjukan hasil uji reliabilitas dengan menggunakan alpha cronbach menunjukan nilai lebih dari 0,6 yang berarti menunjukan instrumen reliabel.

\section{Hasil Uji Hipotesis Pengaruh Parsial (Uji t)}

Tabel 4.3 : Coefficients ${ }^{a}$

\begin{tabular}{|c|c|c|c|c|c|c|}
\hline \multirow[b]{2}{*}{ Mode } & & \multicolumn{2}{|c|}{ Unstandardized Coefficients } & $\begin{array}{l}\text { Standardized } \\
\text { Coefficients }\end{array}$ & \multirow[b]{2}{*}{$\mathrm{t}$} & \multirow[b]{2}{*}{ Sig. } \\
\hline & & $\mathrm{B}$ & Std. Error & Beta & & \\
\hline \multirow[t]{4}{*}{1} & (Constant) & 6.184 & 1.552 & & 3.983 & .000 \\
\hline & $\mathrm{x} 1$ & .243 & .087 & .264 & 2.786 & .006 \\
\hline & $\mathrm{x} 2$ & .169 & .073 & .220 & 2.318 & .023 \\
\hline & x3 & .367 & .107 & .316 & 3.441 & .001 \\
\hline
\end{tabular}

a. Dependent Variable: $y$

Sumber : Data Primer. Diolah 2018

Berdasarkan tebel 4.3 maka berikut adalah hasil analisisnya :

1. Dimensi Family Types (X1)

Dimensi Family Types (X1) mempunyai t hitung sebesar 2.786 lebih besar dari t table 1.986, dengan nilai signifikansi 0.06 kurang dari sama dengan 0.05, maka $\mathrm{H}_{0}$ ditolak dan $\mathrm{H}_{\mathrm{a}}$ diterima. Berdasarkan hasil ini dapat disimpulkan bahwa Family Types berpengaruh secara signifikan terhadap keputusan pembelian mobil keluarga. Hal ini berarti apabila semakin tingginya perhatian konsumen terhadap kebutuhan serta pendapat dari keluarga inti akan meningkat kan keputusan pembelian mobil keluarga.

Berdasarkan wawancara dengan responden, mereka menyatakan bahwa hal Yang terpenting dalam pembelian mobil keluarga adalah kenyamanan seluruh anggota keluarga dalam menggunakan mobil tersebut. Hal ini menyebabkan purchaser yang biasanya adalah orang tua baik istri atau suami menanyakan pendapat dari keluarganya ketika akan membeli mobil tersebut.

Hal ini disebabkan karena mobil keluarga yang akan dibeli lebih banyak digunakan oleh anggota keluarga inti sehingga yang lebih diutama kan adalah pendapat serta 
kebutuhan dari keluarga inti tersebut.

\section{Dimensi Family Stages}

Dimensi Family Stages mempunyai t hitung sebesar 2.318 lebih besar dari t tabel 1.986, dengan nilai signifikansi 0.023 kurang dari sama dengan 0.05, maka $\mathrm{H}_{0}$ ditolak dan $\mathrm{H}_{\mathrm{a}}$ diterima . Berdasarkan hasil ini dapat disimpulkan bahwa Family Stages berpengaruh secara signifikan terhadap keputusan pembelian mobil keluarga. Hal ini berarti apabila semakin banyak pasangan yang berdiskusi serta mengambil keputusan secara bersama-sama akan meningkatkan keputusan pembelian mobil keluarga. Hasil tersebut sesuai dengan pernyataan dari responden yang mengemukakan bahwa produk tersebut membutuhkan dana yang besar untuk membelinya sehingga tentunya mereka akan berdiskusi bersama dengan pasangannya terlebih dahulu sebelum mela kukan pembelian.

Berdasarkan hasil pengujian diatas, hipotesis penelitian yang menduga bahwa dimensi pada dimensi family stages secara parsial berpengaruh secara signifikan terhadap keputusan pembelian, Berdasarkan hasil wawancara dengan beberapa responden didapati bahwa dalam melakukan pembelian mobil keluarga, responden cenderung berdiskusi serta mengambil keputusan pembelian secara bersama-sama dengan pasangannya sekalipun dalam keputusan tersebut dapat didominasi oleh salah satu pihak suami atau istri ataupun seimbang antara keduanya.

3. Dimensi Household decision (X3)

Dimensi Household decision mempunyai t hitung sebesar 3.441 lebih besar dari t tabel 1.986, dengan nilai signifikansi 0.001 kurang dari sa ma dengan 0.05, maka $\mathrm{H}_{0}$ ditola $\mathrm{k}$ dan $\mathrm{H}_{\mathrm{a}}$ diterima . Berdasarkan hasil ini dapat disimpulkan bahwa consencual purchase decision berpengaruh secara signifikan terhadap keputusan pembelian mobil keluarga. Hal ini berarti apabila perbedaan pandangan dalam hal metode pembayaran maupun lokasi pembelian semakin tinggi maka keputusan pembelian mobil keluarga akan semakin tinggi juga. Hal ini disebabkan pada awal mula respoden telah sepakat untuk me mbeli mobil keluarga, namun dalam proses diskusi sekalipun terjadi perbedaan pandangan mengenai lokasi maupun metode pembayaran yang akan digunakan, hal tersebut tidak mengubah keputusan semula untuk membeli mobil keluarga.

Berdasarkan hasil pengujian diatas, hipotesis penelitian yang menduga 
bahwa dimensi pada dimensi household decision secara parsial berpengaruh secara signifikan terhadap keputusan pembelian.

Berdasarkan hasil wawancara dengan beberapa responden didapati bahwa ketika mengambil keputusan pembelian, responden cenderung memiliki pandangan serta keinginan yang sama misalnya responden memilih untuk membeli mobil keluarga karenakan keduanya melihat populasi dari tipe tersebut paling banyak dibeli oleh konsumen, sehingga tidak terjadi perbedaan pendapat mengenai tipe serta harga mobil keluarga yang ingin dibeli. Selain itu mereka juga cenderung mengikuti rekomendasi dari wiraniaga mengenai mobil yang akan dibeli.

\section{Analisis Regresi Linier Berganda}

Tabel 4.1: Hasil Analisis Regresi Berganda

Model Summary

\begin{tabular}{|l|l|l|l|l|}
\hline Model & $R$ & $R$ Square & $\begin{array}{l}\text { Adjusted } \\
\text { Square }\end{array}$ & $\begin{array}{l}\text { Std. Error of the } \\
\text { Estimate }\end{array}$ \\
\hline 1 & $.629^{\mathrm{a}}$ & .396 & .376 & 1.985 \\
\hline
\end{tabular}

a. Predictors: (Constant), x3, x1, x2

ANOVAa
\begin{tabular}{|ll|l|l|l|l|l|}
\hline Model & & Sum of Squares & $\mathrm{df}$ & Mean Square & $\mathrm{F}$ & Sig. \\
\hline 1 & Regression & 237.958 & 3 & 79.319 & 20.121 & $.000^{\mathrm{b}}$ \\
& Residual & 362.667 & 92 & 3.942 & & \\
& Total & 600.625 & 95 & & & \\
\hline
\end{tabular}

a. Dependent Variable: $y$

b. Predictors: (Constant), x3, x1, x2

Sumber : Data Primer. Diolah 2018

Berdasarkan tebel 4.4 maka berikut adalah hasil analisisnya :

\section{a. Nilai Koefisien Korelasi $(R)$}

Koefisien korelasi (R) sebesar 0,629 menunjukkan bahwa hubungan variabel bebas dimensi Family Types (X1), dimensi Family Stages (X2) dan dimensi Household decision (X3) terhadap Keputusan pembelian mobil keluarga adalah cukup kuat.

\section{b. Nilai Koefisien Determinasi (R-Square)}

Nilai koefisien determinasi ( $R$-Square) yang diperoleh adalah 0,376 , me miliki arti bahwa keputusan pembelian mobil keluarga dijelaskan oleh dimensi Family Types (X1), dimensi Family Stages (X2) dan dimensi Household decision(X3) sebesar 37,6 $\%$ dan sisanya yaitu 62,4\% dijelaskan oleh faktor lain yang tidak dimasukkan ke dalam variabel penelitian. 


\section{c. Uji Hipotesis Pengaruh Simultan (Uji F)}

Hasil analisis regresi linier berganda, dapat dilihat bahwa nilai signifikansi uji $\mathrm{F}$ adalah 0.00 atau kurang dari $0.05(\alpha=5 \%)$, maka dapat disimpulkan bahwa variabel bebas dimensi Family Types (X1), dimensi Family Stages (X2) dan dimensi Household decision (X3) secara bersama-sama berpengaruh signifikan terhadap keputusan pembelian mobil keluarga.

\section{KESIMPULAN DAN SARAN}

\section{Kesimpulan}

Dari hasil pembahasan diatas dapat disimpulkan sebagai berikut :

1. Dari hasil uji t dapat disimpulkan bahwa masing masing dimensi variabel family types, family stages, dan household decision mempengaruhi pengambilan keputusan pembelian mobil keluarga secara signifikan.

2. Berdasarkan hasil uji t hitung didapati dimensi yang paling berpengaruh terhadap keputusan pembelian mobil keluarga adalah Household decision (X3) karena $\mathrm{t}$ hitungnya paling besar yaitu 3.441. Berdasarkan dengan hasil wawancara dengan beberapa responden ditemukan bahwa inisiatif untuk membeli mobil keluarga dilakukan dengan melalui semacam konferensi bisnis dikarenakan munculnya perbedaan pendapat, hal ini dikarenakan setiap anggota keluarga memiliki aktivitas dan prioritas yang berbeda beda semisal setuju membeli mobil baru tetapi proses pemeliannya ada yang menginginkan membeli langsung ke dealer atau membeli di saat ada pameran Terdapat juga perbedaan preferensi dan prioritas salah satu keluarga mengingikan pembelian mobil keluarga baru, tetapi salah satu keluarga tidak dapat melihat pentingnya kebutuhan untuk menggantikan mobil yang lama.

3. Dari Uji F, dihasilkan nilai signifikansi di ba wah nilai signifikansi uji F adalah 0.00 atau kurang dari $0.05(\alpha=5 \%)$, maka dapat disimpulkan bahwa variabel bebas dimensi Family Types (X1), dimensi Family Stages (X2) dan dimensi Household decision (X3) secara bersama-sama berpengaruh signifikan terhadap keputusan pembelian mobil keluarga. 


\section{Saran}

Berdasarkan hasil penelitian yang didapatkan diberikan saran untuk perbaikan sebagai berikut:

1. Konsumen mobil keluarga sangat memperhatikan pendapat dari keluarga. Oleh karena itu penulis merasa bahwa perusahaan dapat membuat iklan komersial baik iklan untuk televisi yang berupa video, billboard, maupun iklan di media sosial seperti Youtube. Contohnya di dalam iklan tersebut ditunjukkan sebuah keluarga yang memiliki hubungan harmonis, atau keluarga yang dengan gembira pergi berlibur dengan menggunakan mobil keluarga

2. Selain dengan menggunakan iklan, perusahaan dapat melakukan strategi promosi yang dapat meningkatkan kebersamaan keluarga yang berkaitan dengan mobil keluarga. Misalnya untuk pembelian selama mengalami penurunan akan mendapatkan voucher menginap di resort selama 2 malam bersama keluarga.

\section{Referensi}

Daftar 15 mobil terlaris 2017, Pewarta: Alviansyah Pasaribu; Antara news otomotif rabu 17 Januari 2018

Ikhsan "Penjualan Mobil 2012 Cetak Rekor Tertinggi.". 2013. 14 Januari 2013. www.oto.detik.com

J. Linchosten dan Mansyur. (1983). Pengantar Ilmu Jiwa Fenomenologi. Bandung: Jemmars. Kuncoro, M. (2003). Metode Riset untuk Bisnis dan Ekonomi. Jakarta: Erlangga.

Lackwell, R.D, Engel, J.F, \& Miniard, P.W. (2006). Consumer Behavior, $10^{\text {th }}$ ed. $\quad$ Canada: Thomson South Western.

Sciffman, L.G, Kanuk, L.L. (2007). Consumer Beha- vior, $9^{\text {th }}$ ed. New Jersey: Pearson Prentice Hall

Sciffman, L.G, Kanuk, L.L. (2010). Consumer Beha- vior, $10^{\text {th }}$ ed. New Jersey: Pearson Prentice Hall

Solomon, M.R. (2009). Consumer Behavior: Buying, Having, and Being, $8^{\text {th }}$ ed. New

Jersey: Pearson Prentice Hall

Sugiyono (2010). Metode Penelitian Bisnis: Pende- katan Kuantitatif, Kualitatif dan

$R \& D$. Ban- dung: Alfabeta

Uzulens, Viesturs. (2012) "Joint Decision-making Roles Between Spouses in Latvia When Buying a Family Car” BSc in Business. VU84938. April 2012 <www.pure.au.dk.com> 